\title{
Pengelolaan Database Untuk Administrasi Perkantoran Menggunakan Microsoft Access 2007 Bagi Siswa SMK Abdi Negara 2 Cibarusah
}

\author{
Mira Ziveria $^{1)}$, Edy Winarso ${ }^{2)}$, Poltak Pancarian Situmorang ${ }^{3)}$ \\ Sistem Informasi, Institut Teknologi dan Bisnis Kalbis \\ Pulomas Selatan Kav 22 Jakarta Timur 13210 \\ ${ }^{1)}$ Email: mira.ziveria@kalbis.ac.id \\ 2)Email: edywinarso@yahoo.com \\ ${ }^{3)}$ Email: poltak.situmorang@kalbis.ac.id
}

\begin{abstract}
Abdi Negara 2 Cibarusah Vocational High School (SMK) is located on Jalan Raya Cikarang Cibarusah Km 11, Sindang Mulya Village, Cibarusah District, West Java Province. This community service activity is in the form of training provided by lecturers of the Information Systems Study Program at the Institut Teknologi dan Bisnis Kalbis with the topic Database Management for Office Administration Using Microsoft Access 2007 for SMK Abdi Negara 2 Cibarusah Students. This training aims to improve the skills of students majoring in Office Administration practically using Microsoft Access 2007 tools and providing an understanding of the basic concepts and supporting tools of Microsoft Access 2007. The training was held on April 13, 2017 at SMK Abdi Negara 2 Cibarusah. The training which consists of five modules is expected to be very supportive and help students of SMK Abdi Negara 2 Cibarusah to improve their ability to use Microsoft Access 2007 tools.
\end{abstract}

Keywords: training, database, microsoft access, SMK Abdi Negara 2 Cibarusah

Abstrak: Sekolah Menengah Kejuruan (SMK) Abdi Negara 2 Cibarusah terletak di Jalan Raya Cikarang Cibarusah Km 11, Desa Sindang Mulya, Kecamatan Cibarusah, Provinsi Jawa Barat. Kegiatan pengabdian kepada masyarakat ini berupa pelatihan yang diberkan oleh dosen Program Studi Sistem Informasi Institut Teknologi dan Bisnis Kalbis dengan topik Pengelolaan Database Untuk Administrasi Perkantoran Menggunakan Microsoft Access 2007 Bagi Siswa SMK Abdi Negara 2 Cibarusah. Pelatihan ini bertujuan untuk meningkatkan keahlian siswa jurusan Administrasi Perkantoran secara praktikal menggunakan perangkat Microsoft Access 2007 serta memberikan pemahaman mengenai konsep dasar dan perangkat pendukung Microsoft Access 2007. Pelatihan dilaksanakan pada tanggal 13 April 2017 di SMK Abdi Negara 2 Cibarusah. Pelatihan yang terdiri dari lima modul ini diharapkan akan sangat mendukung dan membantu siswa SMK Abdi Negara 2 Cibarusah untuk meningkatkan kemampuan untuk menggunakan perangkat Microsoft Access 2007.

Kata kunci: pelatihan, database, microsoft access, SMK Abdi Negara 2 Cibarusah

\section{PENDAHULUAN}

\section{A. SMK Abdi Negara 2 Cibarusah}

Sekolah Menengah Kejuruan (SMK) adalah salah satu bentuk satuan pendidikan formal yang menyelenggarakan pendidikan kejuruan pada jenjang pendidikan menengah sebagai lanjutan dari SMP/MTs atau bentuk lain yang sederajat atau lanjutan dari hasil belajar yang diakui sama/setara SMP/MTs. Di SMK terdapat banyak sekali Program Keahlian. Sekolah Menengah Kejuruan (SMK) Abdi Negara 2 Cibarusah terletak di Jl. Raya Cikarang Cibarusah Km 11, Desa Sindang Mulya, Kecamatan Cibarusah, Provinsi Jawa Barat. SMK Abdi Negara 2 Cibarusah adalah sekolah swasta dari Yayasan Pendidikan Abdi Negara Bekasi. Berdiri tahun 2004 yaitu tanggal 19 Juli 2004 dan pada saat ini statusnya terakreditasi A. Program keahlian yang terdapat pada SMK ini ada 4 program, yaitu Teknik Instalasi Tenaga Listrik, Teknik Otomitif Kendaraan Ringan, Administrasi Perkantoran, dan Akuntansi. Guru yang mengajar berjumlah 41 orang dan siswanya pada saat ini berjumlah 647 orang. Fasilitas yang dimiliki antara lain: Ruang kelas, perpustakaan, lapangan olah raga, laboratorium dan ruang praktek. Khusus untuk laboratorium komputer, SMK ini memiliki 3 buah laboratorium yang masing-masing laboratorium komputer terdapat sejumlah 30 unit komputer.

Administrasi Perkantoran adalah salah satu program keahlian pada SMK Abdi Negara 2 Cibarusah. Banyak hal yang dipelajari di jurusan ini yang nantinya akan membentuk lulusan yang dapat bekerja pada bidang antara lain: Junior Secretary, 
Resepsionis, Humas, Operator peralatan kantor, Juru tata usaha, Pengelola perpustakaan, dan lain-lain. Administrasi Perkantoran adalah kegiatan sehari-hari yang berfokus pada perencanaan anggaran keuangan, pembayaran dan pendataan suatu perkantoran atau perusahaan. Administrasi kantor bertanggung jawab atas merencanakan kegiatan kantor, menyediakan peralatan kantor, mengatur perubahan antar departemen, seta membantu tugas manajemen senior untuk menggaji dan memberhentikan karyawan.

Untuk menunjang keahlian guru dan siswa program Administrasi Perkantoran, tentunya diperlukan keterampilan dalam mengelola administrasi perkantoran, diantaranya menggunakan progam microsoft office.

Microsoft Office merupakan software aplikasi perkantoran berbasis Windows yang dirancang khusus menyelesaikan pekerjaan administrasi modern yang memiliki tingkat kondisi atau kebutuhan yang berbeda-beda serta tingkat flexibilitas yang tinggi. Program Microsoft Office telah menjadi standar program untuk perkantoran, bisnis dan pendidikan. Keterampilan ini diperlukan oleh guru dan siswa SMK dapat dijadikan sebagai alat bantu di lingkungan kerja atau sebagai media untuk mempermudah proses pengerjaan tugas sehari-hari, sehingga dari pengetahuan yang telah diperoleh tersebut peserta pelatihan ini mampu menggunakannya untuk mengerjakan tugas-tugas seperti membuat dan mengolah dokumen, membuat laporan pembukuan, laporan keuangan, analisa statistik, formulir, database, slide presentasi dll. Beberapa program yang terdapat pada Microsof Office adalah:

1. Microsoft Word (pengolah kata dan surat menyurat). Pengenalan program Word, membuat dokumen, mengatur layout dan format dokumen, menyunting dan menyimpan dokumen, menambahkan footnote dan endnote, header dan footer, naskah berkolom, autocorrect, membuat tabel, menggambar object, menyisipkan object, mencetak dokumen, mail merge.

2. Microsoft Excel (pengolah angka dan keungan). Pengenalan program Excel, membuat lembar kerja elektronik, menyunting \& menyimpan lembar kerja, fasilitas autocorrect, format cell, rumus dan fungsi pada excel, operasi database, mencetak lembar kerja, membuat grafik.

3. Microsoft Access (pengolah database). Pengenalan program Access, membuat database baru, membuat \& mengolah table, memasukan data, manipulasi data, membuat \& mengolah query, form, report, serta penggunaan macro.
4. Microsoft PowerPoint (presentasi dan marketing). Pengenalan program PowerPoint, membuat slide presentasi, mengatur desain slide, memberi background slide, menggunakan template slide, menambahkan animasi slide, efek waktu \& suara, serta menampilkan slide.

Microsoft Access adalah suatu aplikasi yang dapat membantu kita membuat sebuah aplikasi database dalam waktu yang relatif singkat. Biasanya digunakan untuk pembuatan aplikasiaplikasi yang kecil. Misalnya Program untuk Kasir di koperasi, penjualan untuk toko, dan lain-lain.

Pengabdiankepada masyarakat ini dilakukan di SMK Abdi Negara 2 Cibarusah yang berlokasi di Jl. Raya Cikarang Cibarusah Km 11, Desa Sindang Mulya, Kecamatan Cibarusah, Provinsi Jawa Barat.

Berdasarkan uraian diatas, maka masalah yang dihadapi oleh Siswa SMK Abdi Negara 2 Cibarusah adalah masih kurangnya penguasaan aplikasi Microsoft Office terutama Microsoft Office Access bagi siswa Program Keahlian Administrasi Perkantoran yang dapat meningkatkan keterampilan siswa dalam membuat sebuah aplikasi database dalam waktu yang relatif singkat.

Sehubungan dengan hal tersebut diatas dan dalam rangka mewujudkan salah satu Tri Dharma Perguruan Tinggi yaitu pengabdian kepada masyarakat, program studi Sistem Informasi Kalbis Institute akan mengusulkan program pelatihan bagi siswa SMK Abdi Negara 2 Cibarusah yaitu Pengelolaan Database Untuk Administrasi Perkantoran Menggunakan Microsoft Access 2007.

\section{METODE PELAKSANAAN}

\section{A. Topik Kegiatan}

Sebagai program studi yang terkait dengan bidang teknologi dan bisnis maka Prodi Sistem Informasi Kalbis Institute sangat antusias untuk ikut berpartisipasi dalam kegiatan PKM dengan SMK Abdi Negara 2 Cibarusah. Berdasarkan observasi dan wawancara yang dilakukan tim PKM dengan Kepala Sekolah SMK Abdi Negara 2 Cibarusah, mereka membutuhkan pelatihan sistem pengarsipan digital yaitu dengan pembuatan database dengan Microsoft Access 2007 yang dapat menginput data dan mencetak laporan. Oleh karena itu Prodi Sistem Informasi mengusulkan untuk memberikan pelatihan "Pengelolaan Database Untuk Administrasi Perkantoran Menggunakan Microsoft Access 2007 Bagi Siswa SMK Abdi Negara 2 Cibarusah" yang 
dapat mendukung dan membantu siswa untuk membuat sebuah aplikasi database dalam waktu yang relatif singkat.

\section{B. Tujuan Kegiatan}

Tujuan Kegiatan secara khusus adalah Dari kegiatan pelatihan ini, Prodi Sistem Informasi mengharapkan nantinya para siswa SMKAbdi Negara 2 Cibarusah memiliki keahlian secara praktikal untuk pengelolaan database menggunakan Microsoft Office Access 2007. Secara Umum adalah Dari keahlian itu maka nantinya para siswa SMK Abdi Negara 2 Cibarusah diharapkan dapat menunjang kemampuan dalam penggunaan aplikasi Microsoft Office.

\section{Manfaat Kegiatan}

Manfaat kegiatan bagi Program Studi Sistem Informasi adalah pemenuhan kewajiban Pengabdian pada Masyarakat bagi Dosen Prodi, meningkatkan keahlian dosen melalui proses sharing keahlian bagi mitra, memperbanyak relasi dengan mitra untuk berbagai fungsi-fungsi positif, memberikan pengalaman baru bagi dosen-dosen Prodi Sistem Informasi mengenai pemanfaatan teknologi untuk mengelola database menggunakan Microsoft Office.

Manfaat kegiatan bagi siswa SMK Abdi Negara 2 Cibarusah adalah meningkatkan keahlian secara praktikal mengenai Microsoft Access 2007, memberikan pengenalan mengenai konsep dasar dan perangkat pendukung Microsoft Access 2007, memberikan pemahaman-pemahaman baru mengenai dunia kampus Kalbis Institute.

\section{Metode Pendekatan}

Sesuai dengan permasalahan diatas, maka Dosen Program Studi Sistem Informasi Fakultas Ilmu Komputer dan Ilmu Komunikasi Kalbis Institute mengadakan pelatihan dengan tema "Pengelolaan Database Untuk Administrasi Perkantoran Menggunakan Microsoft Access 2007 Bagi Siswa SMK Abdi Negara 2 Cibarusah" pada tanggal 13 April 2017 di SMK Abdi Negara 2 Cibarusah, Jalan Raya Cikarang - Cibarusah KM 11 Ds. Sindang Mulya, Kec. Cibarusah. Tema pelatihan yang ditawarkan adalah:. Tema pelatihan yang ditawarkan adalah: [1]

1. Definisi Arsip dan Kearsipan

2. Tujuan Penyimpanan Arsip

3. Arsip Elektroni

4. Manfaat Manajemen Arsip Elektronik

5. Microsoft Office Access

Memulai Microsoft Access

Table, Field dan Record

\author{
Kunci Primer atau Primary Key \\ Queries \\ Form \\ Report atau Laporan
}

\section{E. Tinjauan Pustaka}

\section{Definisi Arsip Dan Kearsipan}

Arsip sebagai kumpulan warkat yang memiliki kegunaan tertentu, disimpan secara sistematis, dan dapat ditemukan kembali dengan cepat.

Kearsipan yaitu menempatkan kertas-kertas dalam penyimpanan yang baik menurut aturan yang telah ditetapkan terlebih dulu sedemikian rupa, sehingga setiap kertas bila diperlukan dapat ditemukan kembali dengan mudah dan cepat. [1]

\section{Tujuan Penyimpanan Arsip}

Tujuan penyimpanan arsip adalah sebagai pusat ingatan dan informasi jika berkas diperlukan sebagai keterangan; memberi data kepada pegawai yang memerlukan data mengenai hasil-hasil kegiatan dan pekerjaan pada masa lampau; memberikan keterangan vital, sesuai dengan ketentuan perundangundangan. [1]

\section{Arsip Elektronik}

Sistem kearsipan elektronik pada dasarnya memiliki konsep yang sama dengan teknik kearsipan konvensional. Jika pada kearsipan konvensional memiliki kabinet yang secara fisik berfungsi untuk menyimpan dokumen- dokumen penting yang dimiliki perusahaan, maka sitem kearsipan elektronik memiliki kabinet virtual yang di dalamnya berisi map virtual atau folder. Selanjutnya di dalam folder akan berisi lembaran- lembaran arsip yang telah dikonversi ke dalam bentuk file gambar (*.bmp, jpg, dll) atau dokumen (*.doc, txt, dll). [1] seperti pada Gambar 1.

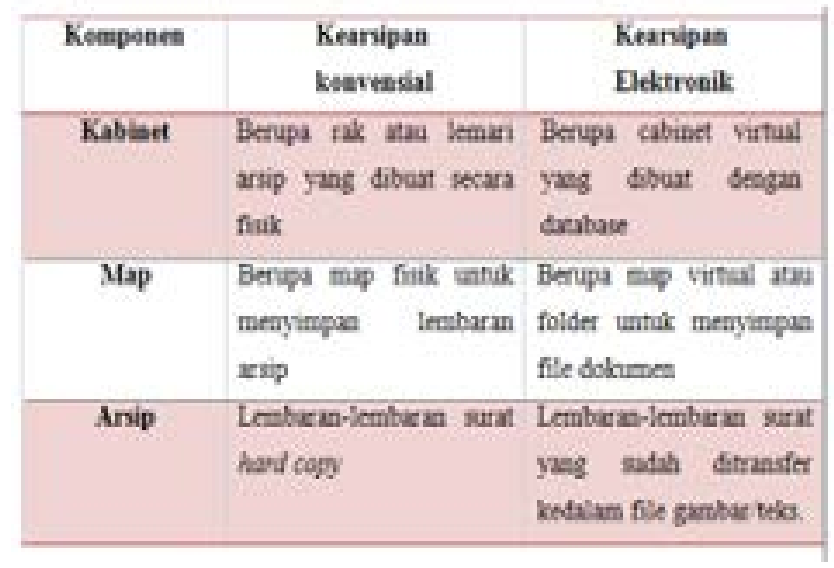

Gambar 1. Perbandingan Kearsipan

Konvensional dan Elektronik 
Kearsipan elektronik berbasis komputer memiliki beberapa kemudahan antara lain:

1. Mudah dioperasikan

2. Tampilan yang menarik

3. Fasilitas pencarian dokumen

4. Pencatatan lokasi fisik dokumen

5. Fasilitas gambar dan suara

6. memiliki keakuratan dalam keamanan data

7. Laporan kondisi arsip

8. Terhubung dengan jaringan computer

\section{Manfaat Manajemen Arsip Elektronik}

Beberapa manfaat penggunaan sistem pengelolaan secara elektonik yang mendorong sebagian besar organisasi untuk mengimplementasikan manajemen arsip elektronik diantaranya adalah: [1]. (1). Cepat ditemukan dan memungkinkan pemanfaatan arsip atau dokumen tanpa meninggalkan meja kerja; (2). Pengindeksan yang fleksibel dan mudah di modifikasi berdasarkan prosedur yang dikembangkan akan menghemat tenaga, waktu, dan biaya; (3). Pencarian secara full-text, dengan mencari file berdasarkan kata kunci maupun nama file dan ditemukan nya dalam bentuk full text dokumen; (4). Kecil kemungkinan file akan hilang, hal ini disebarkan karena kita hanya dapat melihat dilayar monitor atau print-nya tanpa dapat mengubah nya; (5). Memudahkan aksesibilitas dan menjamin akuntabilitas. (6). Mengarsip secara digital, sehingga resiko rusak nya dokumen kertas atau buram karena usia dapat diminimalisir karena tersimpan secara digital; (7). Manajemen pengawasan yang lebih mudah, cepat, dan lebih accountable menuju good governance; dan (8). Mudah dalam melakukan recovery data, dengan memback-up data kedalam media penyimpanan yang compatible.

\section{Microsoft Office Access}

Microsoft Office Access adalah salah satu program pengolahan berbasis data relasional (sekumpulan informasi yang saling berhubungan dan memiliki tujuan tertentu), yang canggih dengan kemudahan penggunaan yang ada seperti pengaturan data, pembuatan form, pembuatan laporan, serta dukungan penuh untuk mengolah berbagai jenis basis data dengan pengoperasian dalam Open Database Connectivity (ODBC) dan teknologi ActiveX Data Objects (ADO) yang membuat Microsoft Office Access sebagai database "default" dalam sistem operasi Windows. [2]

Di dalam berkas tersebut semua objek yang terkait dengan database, termasuk semua tabel disimpan. Berikut fitur-fitur yang masuk dalam MSAccess yaitu: [2]

a. Tabel. Tabel adalah sekumpulan tempat untuk meletakkan, menyimpan, dan mengubah data pada database Access.

b. Query. Query adalah perintah-perintah untuk mengolah data. MS. Access adalah database yang querynya bisa disimpan sehingga jika ingin menggunakannya lagi, tidak perlu susah-susah membuat kembali tapi langsung bisa dijalankan.

c. Form. Form adalah interface atau penghubung antara MS-Access dengan penggunaannya. Tujuan dari form ini adalah agar orang yang mengolah data di MS-Access tidak perlu untuk masuk ke dalam database MS-Access, tetapi cukup dari form yang dibbuat.

d. Report. Report adalah fasilitas untuk menampilkan data ke dalam bentuk laporan yang siap dicetak. Dengan adanya report, informasi hasil pengolahan data lewat query yang dijalankaan di form bisa ditampilkan sebaik mungkin dan se-informatif mungkin. Dengan demikian nilai informasi-nya bisa lebih mudah untuk dipahami oleh orang lain.

\section{Memulai Microsoft Access}

\section{Access}

1. Klik Start pilih Program lalu pilih Microsoft

2. Setelah terbuka klik Blank Database, pada jendela file new database isikan nama file yang diinginkan.

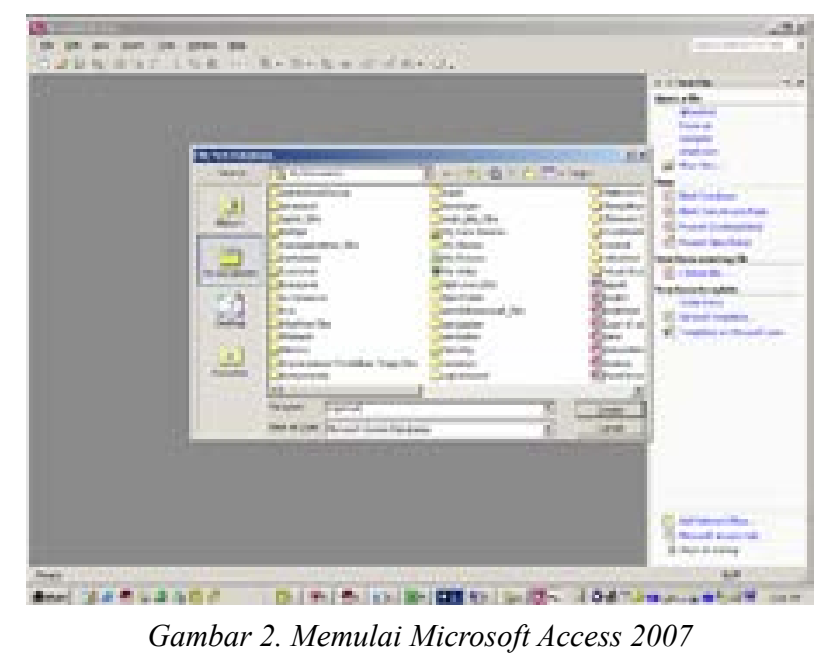

Kita sudah membuat database dengan nama Koperasi tetapi database itu belum dapat digunakan untuk itu kita perlu membuat Tabel, Form, Query, Report dan Macro bila perlu. Seperti pada Gambar 2

\section{Table, Field, Dan Record}

Seperti kita ketahui bahwa database merupakan kumpulan dari beberapa tabel yang terintegrasi menjadi satu kesatuan yang saling berhubungan. 
Tabel merupakan kumpulan dari beberapa record dan fields. Sebagai ilustrasinya adalah seperti pada Gambar 3.

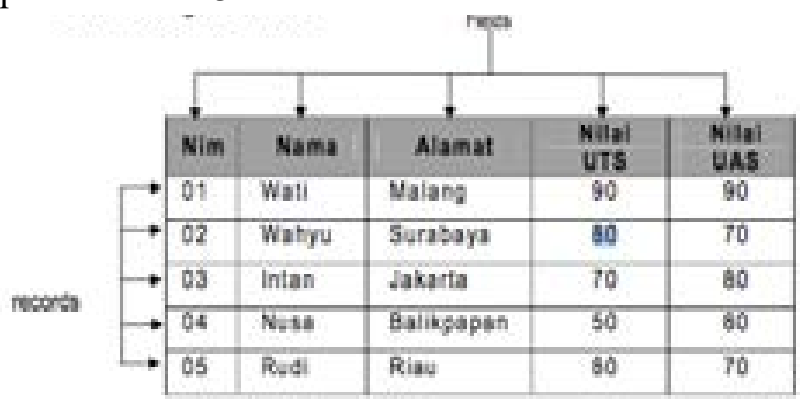

Gambar 3. Fields dan Records pada

Microsoft Access 2007

Jadi yang dimaksud dengan fields adalah atribut yang dimiliki oleh suatu tabel. Sedangkan record adalah isian data yang dimiliki oleh table.

\section{HASIL DAN PEMBAHASAN}

Deskripsi kegiatan pengabdian kepada masyarakat yaitu pelatihan pengelolaan database untuk siswa SMK Abdi Negara 2 Cibarusah pada tanggal 13 April 2017 adalah sebagai berikut:

\section{A. Perencanaan Kegiatan PKM}

Rencana ini didiskusikan dalam rapat Tim Dosen Program Studi Sistem Informasi Fakultas Ilmu Komputer dan Ilmu Komunikasi Institut Teknologi dan Bisnis Kalbis yang tergabung kedalam Tim Pengabdian Kepada Masyarakat (PKM) pada 14 Februari 2017 pukul 13.00 - 17.00 WIB di ruang dosen Lantai 2 Kampus Institut Teknologi dan Bisnis Kalbis, Jalan Pulomas Selatan Kav.22 Jakarta Timur. Diskusi ini untuk membicarakan PKM yang merupakan salah satu wujud Tri Dharma Perguruan Tinggi. Hasilnya adalah kesepakatan untuk melakukan PKM dengan mitra SMK Abdi Negara 2 Cibarusah.

\section{B. Observasi Kegiatan PKM ke SMK Abdi Negara 2 Cibarusah}

Observasi ke Lokasi Mitra PKM ke SMK Abdi Negara 2 Cibarusah yang berlokasi di Jalan Raya Cikarang - Cibarusah KM 11 Ds. Sindang Mulya, Kec. Cibarusah tanggal 18 Februari 2017 pukul 13.00 - 16.00 WIB untuk: Perkenalan kegiatan PKM Prodi Sistem Informasi oleh tim PKM kepada mitra; Pengenalan profil SMK Abdi Negara 2 Cibarusah; Pemberian saran-saran dari para dari Kepala Sekolah SMK Abdi Negara 2 Cibarusah agar kegiatan pengabdian masyarakat tepat sasaran dan bermanfaat bagi siswa dan guru; Identifikasi permasalahan spesifik yang sedang dihadapi mitra; Koordinasi tema pelatihan yang dibutuhkan oleh mitra; dan Koordinasi waktu dan tempat pelaksanaan kegiatan PKM.

\section{Sosialisasi Rencana Kegiatan PKM}

Setelah didapatkan informasi dari hasil observasi ke SMK Abdi Negara 2 Cibarusah, maka Prodi Sistem Informasi melaksanakan rapat perencanaan kegiatan PKM pada tanggal 21 Februari 2017 pukul 13.00 - 17.00 WIB di ruang Yudhistira Lantai 2 Kalbis Institute. Pada rapat ini disosialisasikan road map kegiatan PKM pada Prodi Sistem Informasi untuk semester Genap 2016/2017 dan semester ganjil 2017/2018.

\section{Pembuatan Proposal PKM}

Pembuatan proposal PKM "Pengelolaan Database Untuk Administrasi Perkantoran Menggunakan Microsoft Access 2007 Bagi Siswa SMK Abdi Negara 2 Cibarusah" tanggal 1 Maret 2017 pukul 09.00 - 17.00 WIB oleh tim PKM.

\section{E. Pembuatan Materi Pelatihan PKM}

Pembuatan materi pelatihan PKM "Pengelolaan Database Untuk Administrasi Perkantoran Menggunakan Microsoft Access 2007 Bagi Siswa SMK Abdi Negara 2 Cibarusah" tanggal 3 Maret 2017 pukul 09.00 - 17.00 WIB oleh tim PKM.

\section{F. Rapat Tim PKM}

Rapat tim dan persiapan perlengkapan PKM pada tanggal 12 April 2017 pukul 09.00 17.00 WIB. Kegiatan ini adalah mempersiapkan semua perlengkapan PKM seperti cetak spanduk, penggandaan materi pelatihan, persiapan kendaraan menuju lokasi, pembuatan surat-surat yang dibutuhkan untuk kegiatan PKM, dan lain-lain. Kemudian dilakukan juga rapat semua anggota yang akan berangkat ke lokasi PKM, briefing mahasiswa serta pendalaman materi pelatihan.

\section{G. Pelaksanaan PKM}

Kegiatan pelatihan dilaksanakan selama satu hari yaitu tanggal 13 April 2017 pukul 08.00 - 17.00 WIB, bertempat di SMK Abdi Negara 2 Cibarusah. Pelatihan diberikan oleh Tim PKM dari Prodi Sistem Informasi yang berjumlah lima orang yang terdiri dari tiga orang dosen dan dua orang mahasiswa. Peserta pelatihan adalah siswa dan guru SMK Abdi Negara 2 Cibarusah Program Keahlian Administrasi Perkantoran yang berjumlah 35 orang.

Acara dimulai dengan penyambutan tim PKM dari Prodi Sistem Informasi Kalbis Institute oleh 
Kepala Sekolah dan Guru-Guru SMK Abdi Negara 2 Cibarusah. Kemudian dilanjutkan dengan perkenalan Kepala Sekolah dan Guru-guru SMK Abdi Negara 2 Cibarusah oleh Kepala Sekolah SMK Abdi Negara 2 Cibarusah Bapak Mus Mulyadi, S.E. Setelah itu dilanjutkan dengan sambutan dan perkenalan tim PKM oleh Kaprodi Sistem Informasi Ibu Ridha Sefina Samosir, S.Si., M.Kom.

Pada pukul 09.00 - 10.30 WIB acara pelatihan "Pengelolaan Database Untuk Administrasi Perkantoran Menggunakan Microsoft Access 2007" dimulai dengan instruktur Ibu Mira Ziveria, dengan materi Definisi Arsip dan Kearsipan, Tujuan Penyimpanan Arsip, Arsip Elektronik, dan Manfaat Manajemen Arsip Elektronik. Pada pukul 10.30 12.00 WIB acara dilanjutkan dengan instruktur Ibu Melissa Indah Fianty, S.Kom., M.M.S.I. dengan materi Memulai Microsoft Access, Table, Field dan Record, Kunci Primer atau Primary Key, Queries, Form, dan Report.

Setelah istirahat pukul $12.00-13.00$ WIB acara kembali dilanjutkan dengan pelatihan modul berikutnya yaitu melakukan praktek 1 dengan instruktur Bapak Edy Winarso, yaitu pukul 13.00 - 14.00 WIB. Pada pukul 14.00 - 15.00 WIB acara dilanjutkan dengan instruktur Abia Stevien Karsten dengan materi Praktek 2. Pada pukul $15.00-16.00$ WIB acara dilanjutkan dengan instruktur Ari Kumbang dengan materi Praktek 3. Pukul $16.00-$ 16.30 WIB pada akhirnya acara ditutup oleh Ketua Pelaksana PKM yaitu Ibu Mira Ziveria, dan foto bersama. Pada pukul 16.30 - 17.00 WIB diakhiri dengan pemberian sertifikat kepada semua peserta dan instruktur pelatihan. Pelaksanaan kegiatan dapat dilihat pada Gambar 5 sampai dengan Gambar 10.

\section{H. Evaluasi Kegiatan PKM}

Evaluasi dan pembuatan laporan akhir atas pelatihan yang telah diberikan di ruang dosen Lantai 2 Kampus Institut Teknologi dan Bisnis Kalbis, Jl. Pulomas Selatan Kav.22 Jakarta Timur direncanakan pada awal 17 April 2017 pukul 09.00 - 17.00 WIB.

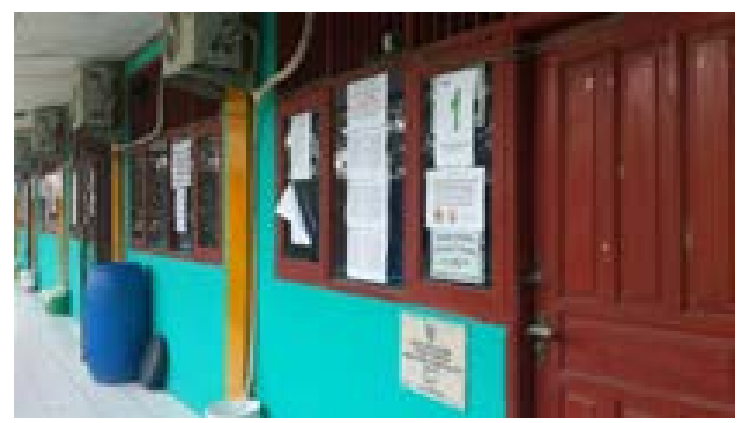

Gambar 5. Laboratorium Komputer

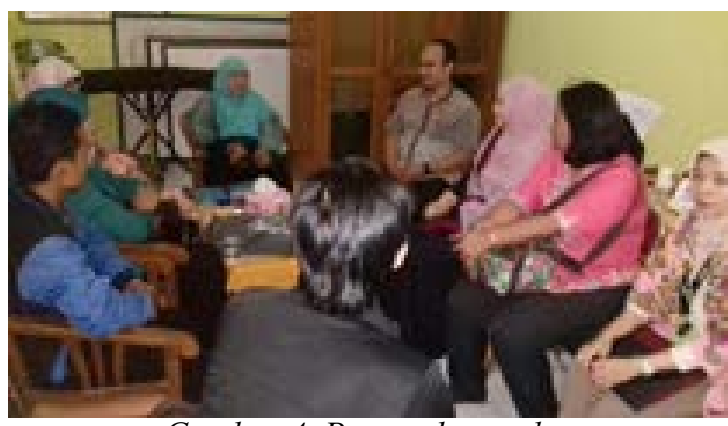

Gambar 4. Penyambutan dan perkenalan tim PKM

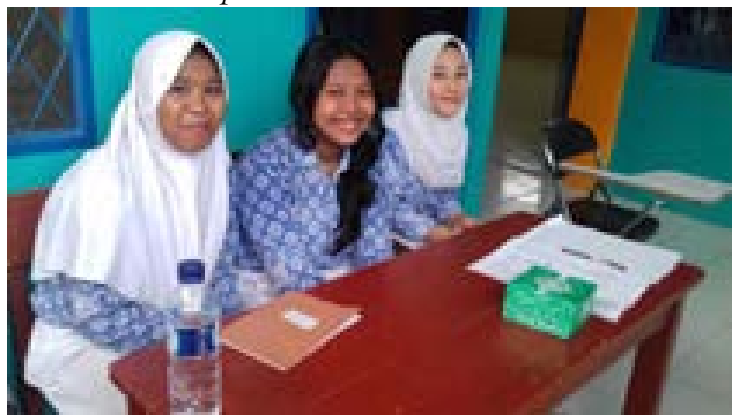

Gambar 5. Siswa SMK Abdi Negara 2 Cibarusah

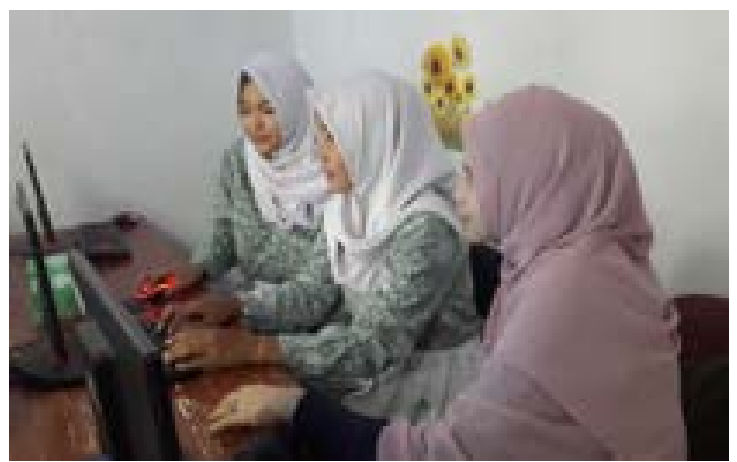

Gambar 6. Ibu Mira Ziveria S.Si., M.T. mengajarkan materi Definisi Arsip

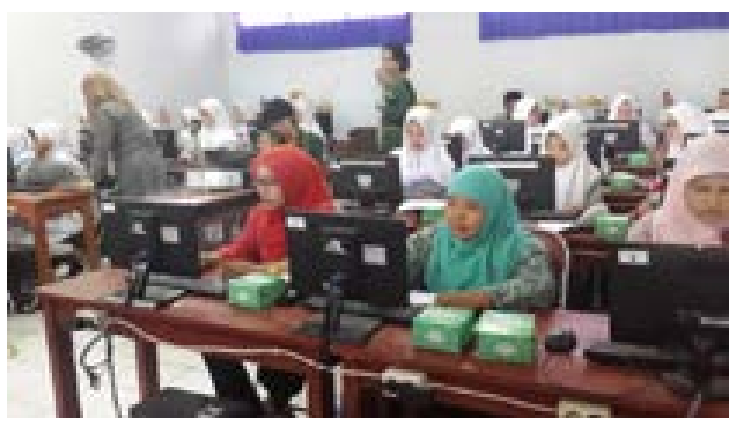

Gambar 7. Peserta pelatihan

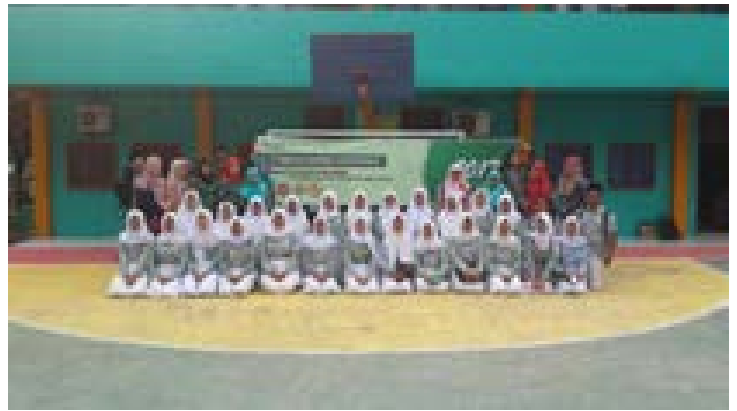

Gambar 10. Para siswa SMK Abdi Negara 2 Cibarusah 


\section{Jadwal Pelatihan}

Jadwal pelaatihan dapat dilihat pada Tabel 1.

Tabel 1. Jadwal Pelatihan PKM

\begin{tabular}{|c|c|c|}
\hline Waktu & Kegiatan & Pelaksanaan \\
\hline $\begin{array}{l}08.00- \\
08.30\end{array}$ & $\begin{array}{l}\text { Sambutan oleh Kepala } \\
\text { Sekolah dan Guru-guru } \\
\text { SMK Abdi Negara } 2 \\
\text { Cibarusah }\end{array}$ & $\begin{array}{l}\text { Mus } \\
\text { Mulyadi, } \\
\text { S.E. }\end{array}$ \\
\hline $\begin{array}{l}08.30- \\
09.00\end{array}$ & $\begin{array}{l}\text { Sambutan dan perkenalan } \\
\text { tim PKM oleh Kaprodi } \\
\text { Sistem Informasi }\end{array}$ & $\begin{array}{l}\text { Ridha Sefina } \\
\text { Samosir, } \\
\text { S.Si., } \\
\text { M.Kom. }\end{array}$ \\
\hline $\begin{array}{l}09.00- \\
10.30\end{array}$ & $\begin{array}{l}\text { Pelatihan dengan materi: } \\
\text { Definisi Arsip dan } \\
\text { Kearsipan } \\
\text { Tujuan Penyimpanan } \\
\text { Arsip } \\
\text { Arsip Elektronik } \\
\text { Manfaat Manajemen } \\
\text { Arsip Elektronik }\end{array}$ & $\begin{array}{l}\text { Mira Ziveria, } \\
\text { S.Si., M.T }\end{array}$ \\
\hline $\begin{array}{l}10.30- \\
12.00\end{array}$ & $\begin{array}{l}\text { Pelatihan dengan materi: } \\
\text { Microsoft Office Access } \\
\text { Memulai Microsoft } \\
\text { Access } \\
\text { Table, Field dan Record } \\
\text { Kunci Primer atau } \\
\text { Primary Key } \\
\text { Queries } \\
\text { Form } \\
\text { Report }\end{array}$ & $\begin{array}{l}\text { Edy Winarso, } \\
\text { S.Kom., } \\
\text { M.M. }\end{array}$ \\
\hline $\begin{array}{l}12.00- \\
13.00\end{array}$ & Istirahat & \\
\hline $\begin{array}{l}13.00- \\
14.00\end{array}$ & $\begin{array}{l}\text { Pelatihan dengan materi: } \\
\text { Praktik } 1\end{array}$ & $\begin{array}{l}\text { Mira Ziveria, } \\
\text { S.Si., M.T }\end{array}$ \\
\hline $\begin{array}{l}14.00- \\
15.00\end{array}$ & $\begin{array}{l}\text { Pelatihan dengan materi: } \\
\text { Praktik } 2\end{array}$ & $\begin{array}{l}\text { Edy Winarso, } \\
\text { S.Kom., } \\
\text { M.M. }\end{array}$ \\
\hline $\begin{array}{l}15.00- \\
16.00\end{array}$ & $\begin{array}{l}\text { Pelatihan dengan materi: } \\
\text { Praktik } 3\end{array}$ & $\begin{array}{l}\text { Mira Ziveria, } \\
\text { S.Si., M.T }\end{array}$ \\
\hline $\begin{array}{l}16.00- \\
16.30\end{array}$ & $\begin{array}{l}\text { Penutupan acara pelatihan } \\
\text { oleh ketua pelaksanaan } \\
\text { PKM. }\end{array}$ & $\begin{array}{l}\text { Edy Winarso, } \\
\text { S.Kom., } \\
\text { M.M. }\end{array}$ \\
\hline $\begin{array}{l}16.30- \\
17.00\end{array}$ & $\begin{array}{l}\text { Pemberian Sertifikat } \\
\text { kepada Peserta pelatihan }\end{array}$ & $\begin{array}{l}\text { Mira Ziveria, } \\
\text { S.Si., M.T }\end{array}$ \\
\hline
\end{tabular}

\section{SIMPULAN}

Kegiatan PKM yang telah dilaksanakan pada tanggal 13 April 2017 dapat disimpulkan bahwa kegiatan ini memberikan pengetahuan baru bagi siswa dan guru Program Keahlian Administrasi Perkantoran pada SMK Abdi Negara 2 Cibarusah mengenai pengelolaan database menggunakan Microsoft Access 2007. Para peserta terlihat sangat antusias mengikutinya karena materi pelatihan sesuai dengan kebutuhan peserta. Keingintahuan peserta sangat besar, hal ini menjadikan materi pelatihan dapat tersampaikan secara keseluruhan.

Dengan memeperhatikan besarnya minta peserta mengikuti pelatihan ini, maka disarankan untuk dapat diberikan pelatihan lanjutan tentang aplikasi komputer Microsoft Office Access dan aplikasi Microsoft Office lainnya, seperti Microsoft Excel dan Power Point agar peserta dapat lebih menguasai aplikasi Micrososft Office. Selain itu, pelatihan dengan tema ini dapat diberikan pada siswa dan guru dari SMK atau SMU lainnya yang belum menguasai aplikasi Micrososft Office.

\section{DAFTAR RUJUKAN}

[1] Amsyah, Zulkifli (2005). Manajemen Kearsipan. PT Gramedia Pustaka Utama. Jakarta.

[2] Winpec Solution (2007). Mudah Menguasai Microsoft Access 2007. PT Elex Media Komputindo. Jakarta 